\title{
ANALISIS PENGARUH PENDAPATAN RUMAH TANGGA TERHADAP KONSUMSI DAGING DAN TELUR DI KECAMATAN SULUUN TARERAN KABUPATEN MINAHASA SELATAN
}

\section{Elvis . F Weol*, B. Rorimpandey**, G. D. Lenzun**, dan E. K. M. Endoh** \\ Fakultas Peternakan Universitas Sam Ratulangi, Manado 95115}

\begin{abstract}
ABSTRAK
Kecamatan Suluun Tareran merupakan salah satu wilayah yang terletak di kabupaten Minahasa Selatan. Mayoritas masyarakatnya sebagai petani dan hanya sebagian kecil yang bekerja sebagai pegawai negeri, pegawai swasta dan wiraswata. Masyarakat dalam mengkonsumsi daging dan telur banyak tergantung dari pendapatan yang diperoleh. Semakin tinggi pendapatan maka kecendrungan untuk mengkonsumsi daging dan telur semakin tinggi. Permasalahan penelitian ini ialah apakah konsumsi daging dan telur di Kecamatan Suluun Tareran dipengaruhi oleh pendapatan rumah tangga responden. Tujuan penelitian ialah untuk mengetahui berapa jumlah konsumsi daging dan telur pada rumah tangga dan pengaruh pendapatan rumah tangga responden terhadap konsumsi

*Alumni Fakultas Peternakan *Jurusan Sosial Ekonomi Peternakan
\end{abstract}

daging dan telur di Kecamatan Suluun Tareran. Jumlah sampel dalam penelitian ini sebanyak 74 rumah tangga responden. Waktu penelitian dan pengumpulan data selama 2 bulan. Metode penelitian yang digunakan adalah metode survey. Analisis yang digunakan adalah analisis regresi sederhana. Hasil penelitian menunjukkan ratarata pendapatan rumah tangga responden adalah $\mathrm{Rp} 2.558 .050$ per bulan. Konsumsi daging belum mencapai target sesuai yang di anjurkan widyakarya pangan dan gizi tahun 2004 yaitu baru sebesar 7.7 $\mathrm{kg} / \mathrm{kapita} / \mathrm{tahun}$ dan telur sebesar 4.1 $\mathrm{kg} / \mathrm{kapita} / \mathrm{tahun}$. Hasil analisis menunjukkan pendapatan rumah tangga responden berpengaruh nyata terhadap konsumsi daging dan telur di Kecamatan Suluun Tareran.

\section{Kata Kunci : Konsumsi daging- telur, Pendapatan}


ABSTRACT

HOUSEHOLD

ANALYSIS AND ITS EFFECT ON MEAT AND EGG CONSUMPTION AT SULUUN TARERAN DISTRICT

\section{OF SOUTH MINAHASA}

REGENCY. District of Suluun Tareran

is the area located in the regency of South Minahasa. The majority of Suluun

Tareran district communities are working household farmers and minority of this community are working as civil servants, private employees and bussinesman. The community consumption of meat and eggs depends largely on the income earned. The tendency of increased consumption of meat and eggs depends also on the increased income of the community in this regency. The higher the income the higher also the deman tendency to consume meat and egg. The problem of this study is that are the consumptions of meat and eggs in the District Suluun Tareran influenced by household income? The purpose of this study was to evaluate the amount of meat and egg consumptions of the household and to determine the effect of household income on the consumption of meat and eggs at the district of Suluun Tareran. This research has been conducted in the district of Suluun Tareran involving the total sample of 74 respondent of households. Data collection of this research was conducted during 2 months using survey method. The data waere analysed using simple regression analysis to determine the effect of income on consumption of meat and eggs. The results showed that the average household income was $\mathrm{Rp}$ $2,558,050$ per month. Meat and egg consumption have not reached the new target of $7.7 \mathrm{~kg}$ and $4.1 \mathrm{~kg}$ per capita per year, respectively; to fulfill the appropriate food and nutrition work recommended by widyakarya in 2004 . The analysis showed that the household income significantly affect the consumption of meat and eggs in the District of Suluun Tareran

Keywords: Meat-egg

consumption, Household Income, Suluun Tareran district

\section{PENDAHULUAN}

Kekurangan protein yang menjadi salah satu penyebab buruknya status gizi penduduk, hingga saat ini masih menjadi masalah yang cukup merisaukan. Kekurangan konsumsi protein diduga sebagai salah satu penyebab gizi buruk, walaupun bukan satu-satunya penyebab, yang diakibatkan oleh rendahnya taraf perekonomian 
penduduk. Protein yang mampu dikonsumsi belum tentu berkualitas, sebab yang disebut dengan sumber protein berkualitas seperti dari hasilhasil peternakan harganya relatif mahal jika dibandingkan dengan protein nabati. Pola makan pun cukup mempengaruhi kualitas protein yang dikonsumsi. Kebanyakan penduduk mengkonsumsi protein yang berasal dari tumbuh-tumbuhan, hal ini karena sebagian masyarakat yang berpenghasilan menengah keatas telah membatasi mengkonsumsi daging asal ternak dengan alasan kesehatan (seperti peningkatan kolesterol).

Rachman (2001) menyatakan bahwa, capaian konsumsi protein untuk penduduk Indonesia jika dibandingkan dengan angka rata-rata kecukupan protein yang disyaratkan pada Widyakarya Pangan dan Gizi Tahun 2004 (LIPI, 2004) yaitu 46,20 gram/kapita/hari, maka angka konsumsi protein 55,23 gram/kapita/hari tahun 2009 telah melebihi yang dianjurkan, artinya secara kuantitas sudah mencukupi. Masalahnya capaian konsumsi protein hewani belum mencukupi sebagaimana anjuran Widya karya pangan dan gizi bahwa, norma gizi protein hewani sebesar 15 gram/kapita/hari. Standar kebutuhan protein hewani ini diharapkan 9 gram/kapita/hari bersumber dari komoditi perikanan dan 6 gram/kapita/hari bersumber dari komoditi peternakan yang setara dengan daging 10,3 kg/kapita/tahun, telur $6,5 \mathrm{~kg} / \mathrm{kapita} / \mathrm{tahun}$, dan susu 7,2 $\mathrm{kg} / \mathrm{kapita} /$ tahun juga masih belum tercapai. Masyarakat Sulawesi Utara khususnya, sampai saat ini standar konsumsi protein hewani asal ternak belum tercukupi yaitu baru sebesar $\quad 4,84 \quad$ gr/kapita/hari sedangkan untuk konsumsi protein asal ikan sebesar 14,41 gr/kapita/hari (Dinas Ketahanan Pangan Sulut, 2010).

Kecamatan Suluun Tareran merupakan salah satu kecamatan yang ada di Kabupaten Minahasa Selatan. Kecamatan Suluun Tareran memiliki jumlah KK sebanyak 2.554 orang serta jumlah penduduk 8.172 orang. Masyarakat di Kecamatan Suluun Tareran pada umumnya mengkonsumsi produk asal ternak berupa daging dan telur, hal ini pun 
didukung oleh faktor sosial budaya dari masyarakat setempat.

Permasalahannya, Kecendrungan peningkatan konsumsi daging dan telur tergantung pada pendapatan masyarakat disuatu wilayah. Semakin tinggi pendapatan maka kecendrungan untuk mengkonsumsi daging dan telur semakin tinggi. Rumusan masalah dalam penelitian ini ialah apakah konsumsi daging dan telur di Kecamatan Suluun Tareran dipengaruhi oleh pendapatan rumah tangga responden. Berdasarkan rumusan masalah maka, tujuan penelitian ini ialah Untuk mengetahui berapa jumlah konsumsi daging dan telur pada rumah tangga responden dan untuk mengetahui pengaruh pendapatan rumah tangga responden terhadap konsumsi daging dan telur di Kecamatan Suluun Tareran.

\section{MATERI DAN METODE PENELITIAN}

Penelitian ini telah dilaksanakan di Kecamatan Suluun Tareran Kabupaten Minahasa Selatan. Waktu pelaksanaan penelitian selama dua bulan yaitu mulai bulan Maret sampai bulan April 2013.
Teknik pengumpulan data menggunakan metode survey. Data diperoleh dari data primer dan data sekunder. Data primer diperoleh secara langsung dari responden melalui wawancara dengan menggunakan daftar pertanyaan. Data primer meliputi identitas responden (Nama, Umur, Pendidikan, Pekerjaan dan jumlah Anggota keluarga), tingkat pendapatan rumah tangga dan jumlah konsumsi daging dan telur. Data sekunder diperoleh dari instansi yang terkait dengan penelitian ini, antar lain Dinas Pertanian dan Peternakan Sulut, Dinas Ketahanan Pangan Sulut, Kantor Kecamatan Suluun Tareran dan Badan Pusat Statistik (BPS) Sulawesi Utara.

Penentuan sampel responden untuk keperluan penelitian dilakukan secara purposive sampling dengan kriteria rumah tangga yang mengkonsumsi produk asal ternak yaitu daging dan telur. Penentuan sampel rumah tangga sebagai responden dilakukan secara simple random sampling (Arikunto, 2002 dan Daniel 2001) yaitu sampel yang di ambil secara acak sederhana sebanyak $10 \%$ dari jumlah rumah 
tangga (KK) pada masing-masing sampel sebagai responden dapat desa sampel. Jumlah rumah tangga dilihat pada Tabel 1.

\section{Tabel 1. Nama Desa, Jumlah KK dan Jumlah Sampel}

\begin{tabular}{llll}
\hline No & Nama desa & Jumlah KK & Jumlah sampel (10\%) \\
\hline 1. & Suluun Tiga & 321 & 32 \\
2. & Talaitad & 423 & 42 \\
\hline Total & & 744 & 74 \\
\hline
\end{tabular}

Definisi variabel penelitian dan pengukurannya dalam penelitian ini menyangkut (i) Responden rumah tangga ialah suatu keluarga yang terdiri dari Ayah, Ibu dan Anak serta orang lain yang termasuk dalam tanggungan yang tinggal serumah dan makan sedapur, dinyatakan dalam satuan kepala keluarga; (ii) Pendapatan ialah nilai rupiah yang diperoleh setiap individu yang tinggal serumah melalui mata pencariannya atau dari sumbersumber lain, dinyatakan dalam rupiah per bulan; (iii) Konsumsi daging dan telur yaitu jumlah daging dan telur yang dibeli dan dikonsumsi selama satu bulan oleh seluruh anggota keluarga, dinyatakan dalam satuan kilogram per bulan.

$\begin{array}{lrr}\text { Berdasarkan variabel dan } & \text { dalam } \\ \text { pengukurannya, maka } & \text { diaknan beberapa }\end{array}$

asumsi-asumsi yang bermanfaat untuk membatasi satuan pengukuran variabel-variabelnya. Asumsi-asumsi tersebut yaitu :

a). Jumlah daging dan telur yang dibelli diasumsikan dikonsumsi oleh rumah tangga responden, kecuali yang dibeli untuk acara pesta atau syukuran dengan mengundang orang lain untuk mengkonsumsi daging dan telur tidak dihitung dalam penelitian ini.

b). Apabila ada anggota rumah tangga yang mengkonsumsi daging dan telur diluar rumah (rumah makan atau acara pesta/rumah orang lain) tidak dihitung dalam penelitian ini.

Data yang diperoleh dalam penelitian ini ditabulasi dan dianalisis melalui pendekatan analisis deskriptif dan matematik. 
Model analisis secara deskriptif dilakukan terhadap data konsumsi daging dan telur serta pendapatan rumah tangga yang diformulasikan dalam besaran nilai mutlak (Rp/bulan) ataupun dalam kilogram (Kg/bulan) dan diinterpretasikan dalam bentuk proporsi atau persentase. Sedangkan model analisis matematik dilakukan dengan menggunakan pendekatan model analisis koefisien regresi sederhana (Akbar dan Usman, 2000) sebagai berikut :

$$
\mathrm{C}=\mathrm{a}+\mathrm{bY}
$$

Keterangan :

$\mathrm{C}=$ Konsumsi daging dan telur

$\mathrm{Y}=$ Pendapatan rumah tangga responden

$$
\begin{gathered}
\mathrm{a}=\underset{\substack{\text { Koefisien } \\
\text { konstanta) }}}{\text { arah }} \\
\mathrm{b}=\begin{array}{c}
\text { Koefisien parameter } \\
\text { pendapatan }
\end{array}
\end{gathered}
$$

Pengujian hipotesis, apakah terdapat pengaruh tingkat pendapatan terhadap konsumsi daging dan telur pada rumah tangga responden di Kecamatan Suluun Tareran digunakan uji t-hitung

\section{HASIL DAN PEMBAHASAN}

\section{Pendapatan Responden}

Pendapatan adalah jumlah penghasilan riil dari seluruh anggota rumah tangga yang disumbangkan untuk memenuhi kebutuhan bersama maupun perseorangan dalam rumah tangga. Pendapatan rumah tangga responden yang diperoleh pada saat penelitian bervariasi yaitu terendah sebesar Rp. 800.000,- per bulan, sedangkan yang tertinggi adalah Rp.6.695.000,- per bulan. Total pendapatan rumah tangga responden secara keseluruhan adalah Rp.189.295.700,- dengan rata-rata Rp.2.558.050,- per rumah tangga responden per bulan. Selain itu total pengeluaran rumah tangga responden untuk konsumsi daging dan telur adalah Rp 8.011.000,- per bulan dengan rata-rata pengeluaran rumah tangga responden dalam mengkonsumsi daging dan telur yaitu sebesar Rp. 108.257,- . Menurut Sajogyo (1997), pendapatan seseorang sangat berpengaruh terhadap pemilihan pangan yang akan dikonsumsi. Pendapatan yang semakin tinggi menyebabkan semakin baik juga seseorang dalam memilih pangan yang dikonsumsi. Selain itu, semakin tinggi pendapatan maka seseorang akan memilih pangan yang beragam dan berkualitas untuk dikonsumsinya. 


\section{Tingkat Konsumsi Daging dan Telur}

Berdasarkan hasil penelitian
bahwa masyarakat memberikan
respon yang kurang baik dalam
mengkonsumsi daging. Tingkat
konsumsi daging masih kurang,
karena pada saat penelitian konsumsi
daging/kapita/tahun masih belum
mencapai target nasional seperti
yang dianjurkan oleh Widyakarya
pangan dan gizi tahun 2004 .

Hasil penelitian menunjukkan bahwa jenis daging yang dikonsumsi rumah tangga responden adalah daging babi dan daging ayam. Daging babi merupakan daging yang paling banyak dikonsumsi yakni oleh 64 responden $(86,49 \%)$ sebanyak $104,5 \mathrm{~kg}$ per bulan dan daging ayam yang dikonsumsi oleh 34 responden $(45,95 \%)$ sebanyak $69,1 \mathrm{~kg}$ per bulan. Sedangkan daging sapi saat penelitian tidak ada rumah tangga respoden yang mengkonsumsi. Hal ini dikarenakan tidak tersedianya daging sapi yang dijual dipasar tradisional kecamatan. Kebiasaan masyarakat yang menyebabkan mereka tidak mengkonsumsi daging sapi. Faktor harga yang relatif lebih mahal dibandingkan dengan harga daging ayam dan daging babi yang lebih murah juga mempengaruhi masyarakat sehingga tidak mengkonsumsi daging sapi. Faktor lain adalah adanya pengaruh budaya dan pola konsumsi masyarakat setempat.

Berdasarkan hasil penelitian rata-rata konsumsi daging/kapita/tahun di Kecamatan Suluun Tareran adalah sebesar 7,7 kg/kapita/tahun. Konsumsi sebesar $7,7 \mathrm{~kg}$ terdiri atas daging babi sebesar 4,5 kg/kapita/tahun, daging Ayam 3,2 kg/kapita/tahun Konsumsi sebesar 7,7 kg/kapita/tahun belum mencapai target nasional yaitu sebesar $\quad 10,3 \quad \mathrm{~kg} / \mathrm{kapita} / \mathrm{tahun}$ (Widyakarya pangan dan gizi tahun 2004). Kondisi ini menunjukkan bahwa konsumsi daging di Kecamatan Suluun Tareran sebesar $74,75 \%$ berarti terdapat kekurangan sebesar 25,24\% dari yang dianjurkan, Kondisi tersebut disebabkan oleh karena pada saat penelitian ada asumsi-asumsi yang bermanfaat untuk membatasi satuan pengukuran. Hal tersebut diduga konsumsi daging sudah melebihi dari 7,7 kg/kapita/tahun tetapi karena 
dalam penelitian ini ada asumsi yang membatasi, sehingga konsumsi daging diluar rumah, acara pesta/acara syukuran/rumah makan tidak dihitung dalam penelitian ini. Pengaruh tingkat pendapatan dan tingkat kesadaran konsumsi masyarakat yang belum mengetahui akan pentingnya mengkonsumsi protein hewani asal ternak. Masyarakat beranggapan bahwa apabila mengkonsumsi daging secara berlebihan akan menyebabkan kesehatan yang kurang baik atau bisa menyebabkan terjadinya peningkatan kolestrol.

Hasil penelitian menunjukkan bahwa jenis telur yang dikonsumsi responden dan keluarganya adalah telur ayam ras dan telur ayam buras. Telur ayam ras merupakan telur yang paling banyak dikonsumsi oleh rumah tangga responden yaitu sebanyak 94,5 $\mathrm{kg}$ per bulan. Hal ini disebabkan karena seluruh rumah tangga responden mengkonsumsi telur ayam ras saat penelitian. Sedangkan telur ayam buras sangat jarang dikonsumsi oleh rumah tangga responden yakni hanya sekitar $1,5 \mathrm{~kg}$ per bulan. Rumah tangga responden yang mengkonsumsi telur ayam buras hanya sebanyak 3 rumah tangga masing-masing $1 / 2 \mathrm{~kg}$ per bulan. Salah satu penyebab rumah tangga tidak mengkonsumsi telur ayam buras dikarenakan tidak adanya petani peternak khusus telur ayam buras di daerah penelitian. Masyarakat disana, menjadikan usaha memelihara ternak ayam buras hanya sebagai usaha sampingan. Masyarakat dalam membeli telur ayam buras harus membeli langsung kepada peternak ayam buras tetapi dengan jumlah yang terbatas dan harganya yang relatif lebih mahal dibandingkan dengan harga telur ayam ras.

Berdasarkan hasil penelitian rata-rata konsumsi telur di kecamatan Suluun Tareran hanya $4,1 \mathrm{~kg} / \mathrm{kapita} / \mathrm{tahun}$ sedangkan yang dianjurkan Widya karya pangan dan gizi sebesar 6,5 kg/kapita/tahun. Kondisi ini menunjukkan bahwa konsumsi telur di Kecamatan Suluun Tareran sebesar $63,07 \%$ berarti terdapat kekurangan sebesar 36,93\% dari yang dianjurkan. Kondisi tersebut diduga disebabkan oleh karena tingkat pendapatan dan tingkat kesadaran konsumsi protein 
asal ternak berupa telur masih rendah. Masyarakat belum mengetahui akan pentingnya mengkonsumsi protein hewani asal ternak berupa telur.

\section{Pengaruh Pendapatan Rumah Tangga Terhadap Pengeluaran Konsumsi Daging dan Telur di Kecamatan Suluun Tareran}

Hasil analisis pengaruh pendapatan rumah tangga terhadap konsumsi daging dan telur di Kecamatan Suluun Tareran dinyatakan dalam persamaan sebagai berikut :

$\mathrm{C}=2,240+0,203 \mathrm{Y}$

Nilai $b_{0}$ sebesar 2,240 merupakan titik awal persamaan yang ada pada sumbu C pada grafik konsumsi daging dan telur dan nilai koefisien paramater pendapatan $\left(b_{1}\right)=0,203$. Berdasarkan hasil persamaan, menunjukkan nilai koefisein parameter pendapatan sebesar 0,203 memberi pengertian bahwa, apabila nilai pendapatan keluarga responden berubah satu satuan rupiah, maka akan diikuti perubahan tingkat konsumsi sebesar 0,203 gr atau 0,0002 Kg. Nilai koefisien parameter konstanta $\left(\mathrm{b}_{0}\right)$ sebesar 2,240 berarti konsumsi daging dan telur (C) per bulan sudah sebesar 2,240 atau 0,024 $\mathrm{kg}$ pada saat pendapatan rumah tangga responden belum mengalami perubahan.

Nilai t-hitung yang diperoleh sebesar 2,370 taraf signifikan $\mathrm{t}=$ 0,0204 menunjukkan bahwa pendapatan berpengaruh nyata terhadap konsumsi daging dan telur. Artinya apabila nilai pendapatan rumah tangga berubah (meningkat), maka ada kecenderungan terjadinya perubahan peningkatan terhadap konsumsi daging dan telur di Kecamatan Suluun Tareran. Hasil ini ditunjang oleh penelitian Ambat (2011) tentang analisis konsumsi daging di kecamatan Tikala kota Manado. Hasil penelitian Ambat (2011) menunjukkan bahwa, pendapatan berpengaruh nyata terhadap konsumsi daging. Hal ini sejalan dengan teori ekonomi bahwa semakin tinggi pendapatan maka konsumsi suatu barang akan semakin tinggi (Sugiarto, dkk. 2002).

\section{KESIMPULAN}

Berdasarkan hasil penelitian dapat disimpulkan bahwa :

1 Jumlah konsumsi daging dan telur yang sudah dicapai rumah tangga responden di kecamatan Suluun Tareran, 
yaitu untuk daging sebesar $7,7 \mathrm{~kg} / \mathrm{kapita} / \mathrm{tahun}$ dan telur sebesar 4,1 kg/kapita/tahun, dengan rata-rata pengeluaran rumah tangga responden dalam mengkonsumsi daging dan telur sebesar Rp. 108.257.

2 Pendapatan rumah tangga responden berpengaruh nyata terhadap konsumsi daging dan telur di Kecamatan Suluun Tareran.

\section{SARAN}

Saran dalam penelitian ini adalah perlu dilakukan penelitian lebih lanjut, karena selain faktor pendapatan masih ada faktor lain yang mempengaruhi konsumsi daging dan telur, antara lain faktor budaya/adat istiadat, faktor pola konsumsi masyarakat, pendidikan dan lain sebagainya.

\section{DAFTAR PUSTAKA}

Akbar, S.P dan Usman, H. 2000. Metode Penelitian Sosial. Bumi Aksara. Jakarta.

Ambat, A.G. 2011. Analisis Konsumsi Daging di Kecamatan Tikala Kota
Manado. Skripsi . Fakultas

Peternakan

UNSRAT.

Manado.

Arikunto, S. 2002. Prosedur Penelitian, Suatu Pendekatan Praktek. Edisi Revisi V. Bina Aksara. Yogyakarta.

Daniel M. 2001. Metode Penelitian Sosial Ekonomi. Umi Aksara.

Dinas Ketahanan Pangan SULUT. 2011. Statistik Konsumsi Protein Hewani Dinas Ketahanan Pangan Sulawesi Utara, Manado.

LIPI. 2004. Angka Kecukupan Gizi Bagi Orang Dewasa. Lokakarya Nasional Widya Karya Pangan dan Gizi VIII. Lembaga Ilmu Pengetahuan Indonesia, Jakarta.

Rachman, H.P.S. 2001. Kajian Pola Konsumsi dan Permintaan Pangan di Kawasan Timur Indonesia. Desertasi Doktor Program Pascasarjana Institut Pertanian Bogor. Bogor.

Sayogyo, T. 1997. Garis Kemiskinan dan Kebutuhan Minimum Pangan. LPSB-IPB. Bogor. $299 \mathrm{hlm}$ 
Soemartini. 2007. Pengaruh Variabel

$$
\begin{aligned}
& \text { Makro Terhadap Perubahan } \\
& \text { Konsumsi } \\
& \text { Indonesia. }
\end{aligned}
$$

Sugiarto, T, Helambang, Bugiarto,

R. Sudjan dan S, Kelana. 2002.

$$
\text { Ekonomi Mikro }
$$

(Sebuah Kajian

Komprehensif). Gramedia.

Jakata. 
